\title{
擬似乱数 $\mathrm{M}$ 系列によるスペクトル拡散音波の距離計測への応用
}

\author{
山 根 章 生*·伊与田 健 敏*·崔 龍 雲* \\ 久保田譲*'渡 辺一 弘* \\ Range Measurements Using Spread Spectrum Sound Waves \\ Modulated with Pseudo Random M-sequences \\ Akio Yamane*, Taketoshi IYota*, Yongwoon Chol*, \\ Yuzuru Kubota* and Kazuhiro Watanabe*
}

\begin{abstract}
In order to develop an indoor, local positioning system and evaluate its ranging accuracy, range measurement experiments have been performed using spread spectrum sound waves at audio frequencies of $0.69,3.0$, and $10 \mathrm{kHz}$, for which a relatively broad frequency response can be readily prepared by means of a pair of transmitter-receiver commercially available. A series of the experiments based on the demodulation of spread spectrum sound signals due to M-sequence (Pseudo Random Noise Code) with a 127-code length showed that the range measurement successfully yielded full-scaled ranging errors of less than $1 \%$ as the accuracy for the frequencies of 0.69 and $3.0 \mathrm{kHz}$, and much smaller value of $0.037 \%$ for the full scale distance of $18 \mathrm{~m}$ in the case of $10 \mathrm{kHz}$. The capabilities of noise rejection to super-imposed white noise and signal discrimination between two different M-sequence codes have been also ensured for the phase shift keying modulation on longitudinal elastic waves. Discussions on the measurement precision are interestingly given in terms of the frequency of carrier wave and the traveling distance during the phase shift chip period as an analogy of pseudorange measurements in the global positioning systems.
\end{abstract}

Key Words: spread spectrum, sound wave, M-Sequence, range measurement, global positioning system

\section{1.はじめに}

屋内における人，ものの位置認識が正確にでき札ば実用的 な種々の応用が期待できるであろう，たとえば，病院内の医 師, 看護婦, 患者, また工場内の作業員の行動認識, さらに 局所的には電動工具の作業動線追跡などが挙げられる.また, 人間と共存するだろう自律移動ロボットにとっても自己位置 の認識は, 環境を認識し障害物を回避し, 安全な走行制御を 行なうための意思決定に不可欠な技術課題といえる. 屋内に 設置した種々のランドマークを用いた自己位置認識法 $\left.{ }^{1)}, 2\right)$, 超音波距離センサを用いた方式 ${ }^{3)}$, モニタカメラによる方 式4)などもあるが, 精度の確保, 屋内環境へのランドマーク の設置などによる利便性, リアルタイム性の欠如などの問題 もあり,どれも決定的な自己位置確認の方式とはなり得ない 現状である。

一方, 屋外環境では世界規模の測位システムとして近年 GPS (Global Positioning System) の応用が進んでいる. 複

* 創価大学工学部 八王子市丹木町 1-236

* Faculty of Engineering, University of Soka, 1-236, Tangi, Hachioji, Tokyo

(Received February 26, 2003)

(Revised July 25, 2003)
数衛星からの電波伝播時間から求められた擬似距離より自己 位置を測位し，汎用コードでは単独測位精度で約 $15 \mathrm{~m}^{5)}$ の実 用的な分解能を有している. しかしながら屋内では, 衛星か らの受信感度が極端に低下し, 一般的には利用に適していな い. 屋内に擬似衛星を設置し, GPSのように電波で自己位 置を認識する研究 ${ }^{6)}$ も進められているが, 遠近問題やマルチ パスの影響により精度の高い位置認識が困難である。さらに ほかの精密機器や計測器の誤動作につながる可能性があるの で, 屋内での高周波帯電磁波の利用は嫌われることが多い. 筆者などはこ机までに，電波による GPS の原理をそのま ま音波に置き換えて, 音波で符号分割多重通信を行ない音波 間の干渉を排除し, 室内においても精度の高い測位システム を提案し実験的検討を行なってきた ${ }^{7), 8)}$. 伝播速度が比較的 遅い音波に置き換えることで，直接波と反射波との受信時間 間隔に比較的長い時間を持たせ，マルチパスの問題を軽減し 直接波の識別が容易となる. GPSに比べはるかに低い周波数 であり，かつ固定衛星であることから信号処理の回路構成も 比較的簡便にできる。 また, GPSの原理どおり 1 チップ距離 (符号 1 ビットに対応する信号伝播距離) の 1/10 程度の精 度が確保できるとすると, $40 \mathrm{kHz}$ の超音波では数 $\mathrm{mm}$ から 数 $\mathrm{cm}$ の精度が望めることになる.これまで一般に多方向の 
距離情報を得るために, 複数のパルス超音波センサを用いて いるが, この場合センサ間の干渉が問題となるため, 複数の 超音波センサを時分割で駆動させるスキャニング法 ${ }^{9)}$ や, 送 信信号に相互相関の低いパルスコードを用いて，雑音下でも 影響の少ない測距方法 ${ }^{10)}$ が研究されている. さ扎に，音波に 位相変調を用いた例として, 音波式ガス温度・流量計測 ${ }^{11)}$, パルス压縮を用いた超音波探傷法 ${ }^{12)}$, 同じく実数直交擬似 雑音系列 ${ }^{13)}$ または $\mathrm{M}$ 系列パル ス列による超音波測距 ${ }^{14)}$ など が報告されている。また本研究と同様に，擬似乱数 $\mathrm{M}$ 系列 で位相変調（PSK：Phase Shift Keying）した可聴音波を用 いた研究として, ガス温度計測 ${ }^{11)}$ や海中における多経路伝 播の観測に関する研究 ${ }^{15)}$ もり, 受信利得の大幅な改善が 確認されその有用性が報告されている。本稿では, 擬似乱数 $\mathrm{M}$ 系列で位相変調されたスペクトル搪散音波を屋内空間で用 い, 屋内用 GPS の構成を目的に, 沉用の送受信音源固有の 帯域制限, また周波数の変化に伴う拡散率の違いによって測 距精度が, GPS のアナロジーとしてどう評価できるのかに ついてはじめて実験的検討を行なっている．得ら机た知見は 带域制限をさらに受けやすい沉用超音波送受信音源での屋内 測位の可能性を示唆している.

本研究では, 周波数特性の带域が比較的広い可聴域带の 送受信音源（スピーカ，マイク）を用いて，可聴域 $(0.69$, $3.0,10 \mathrm{kHz})$ に扑けるスペクトル拡散音波による測距実験を 行なった。搬送波周波数 $10 \mathrm{kHz}$ を用いたスペクトル搪散音波 では, 距離範囲 ( 18m) の測距実験において, 誤差として 平均で $0.037 \%$ （距離にして約 $7 \mathrm{~mm}$ ）を得た。可聴帯域を選 んだ理由は; 可聴带域の送受信源の周波数特性は沉用超音波 トランスデューサに比べ拡散帯域を確保しやすく, 带域制限 を緩和した環境でスペクトル拡散の効果を明らかにするため である、本論文では，白色雑音を送信信号に加えた軵雑音評 価, 異なる擬似乱数系列による符号多重分割送信時の信号識 別特性についても実駼的検討を行なった．また，各周波数に おける測距実験では，周波数スペクトルの拡散時の搬送波周 波数と擬似乱数系列に上る位相変調の 1 チップ距離が測距精 度に与える影響についても検討した。

\section{2.スペクトル拡散音波の送信と受信}

\section{1 スペクトル拡散音波の作成と識別}

スペクトル拡散信号は，搬送波である正弦波を擬似乱数 系列で位相変調 ${ }^{16)}$ して作られる。本研究で用いる擬似乱数 系列は M 系列で, Fig. 1 で示される7ビットのシフトレジ ス夕によって生成される。シフトレジス夕の各ビットの值は 7 つの Tap から取り出すことができ, どの Tap の值を用い るかによって異なる乱数系列を発生させることが出来る。こ こで, 系列の周期を $P$ とする. Tap1 と Tap7 の值，もし くは Tap3 と Tap7 の值を用いて系列を発生させる場合には $P=2^{7}-1$ となることがわかっておりり ${ }^{17)}$, この 2 種類の $\mathrm{M}$ 系列を用いる。

送信されるスペクトル拡散信号の波形を Fig. 2 に示す。搬

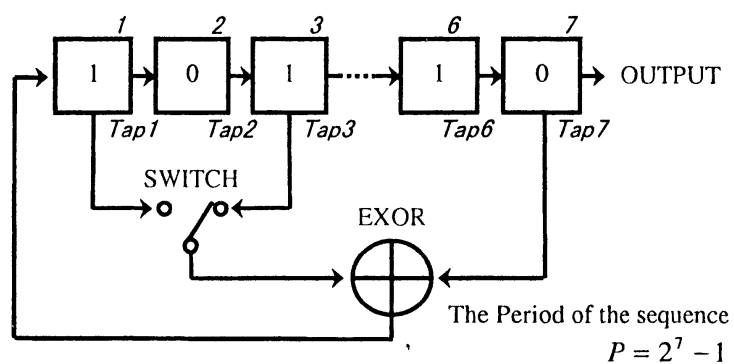

Fig. 1 Maximum length linear shift register sequence to generate 7-bits $\mathrm{M}$-sequences

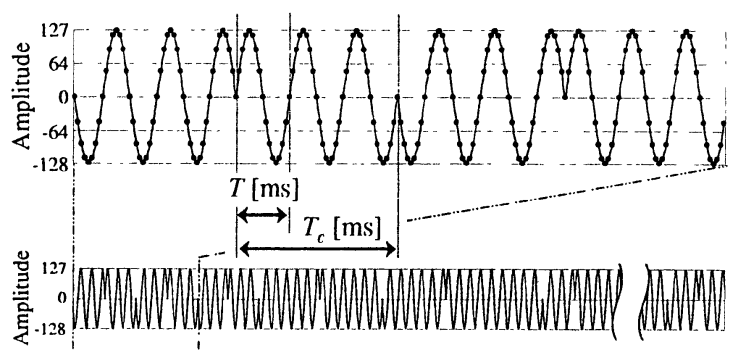

Fig. 2 Spread spectrum signal to be launched from the speaker with phase-shift-keying modulation at every $T_{c}[\mathrm{~ms}]$ on a carrier wave with a period of $T[\mathrm{~ms}]$ which sampled at $T / 16$

送波は周期 $T[\mathrm{~ms}]$ の正弦波である。拡散変調に用いる擬似 乱数系列は先に述べた $\mathrm{M}$ 系列の 0 を -1 に置き換えたもの で，こ机を用いて変調周期 (チップ長) $T_{c}[\mathrm{~ms}]$ ごとに位相変 調を行なっている。ここで用いているスペクトル拡散信号に はデー夕を乗せるための変調を行なっていないので，一般的 にいわ机ている形の拡散率を定義できない。そこで，本研究 ではチップ長に対する擬似乱数系列 1 周期の時間 $T_{p}$ の比, $T_{p} / T_{c}$ で拡散率を定義する。ここで, $T_{p}=T_{c} P$ である.

つぎに，スペクトル拡散した信号を受信し識別するために は，相関值の計算が必要である ${ }^{16)}$. スペクトル拡散信号の処 理は実際にはデジタルデータで行なっており，信号は 8 ビッ トの 2 進数で扱っているので -128 から +127 の間の值を とる。 そのために相関值の最大値は $2^{14} / 2$ となる。 また, 搬 送波周期の $1 / 16$ の時間でサンプリングを行なっており，サ ンプリング周期 $T_{s}=T / 16$ が基本的な時間の単位になる.

Fig. 5 9 の横軸は基本的には時刻 $t$ であるが，各時刻に対 応するサンプリングの番号 $N_{s}$ を用いると $t=N_{s} T_{s}$ と表わ すことが出来るので，横軸には $N_{s}$ を用いている．

\section{2 実験システムの構成}

実験で用いるシステムの構成を Fig. 3 に示寸。システムは スペクトル拡散音波を送り出す送信機と音波を受け取り信号 の識別を行なう受信機から構成されている.

送信機で送り出される音波の波形デー夕はあらかじめ信号 生成部で作成され，波形メモリに記憶される。送信機は波形 データを波形メモリから読み出し D/A 変換部によってアナ ログ電圧に変換され增幅された後, スピーカから音波として 送信する。 


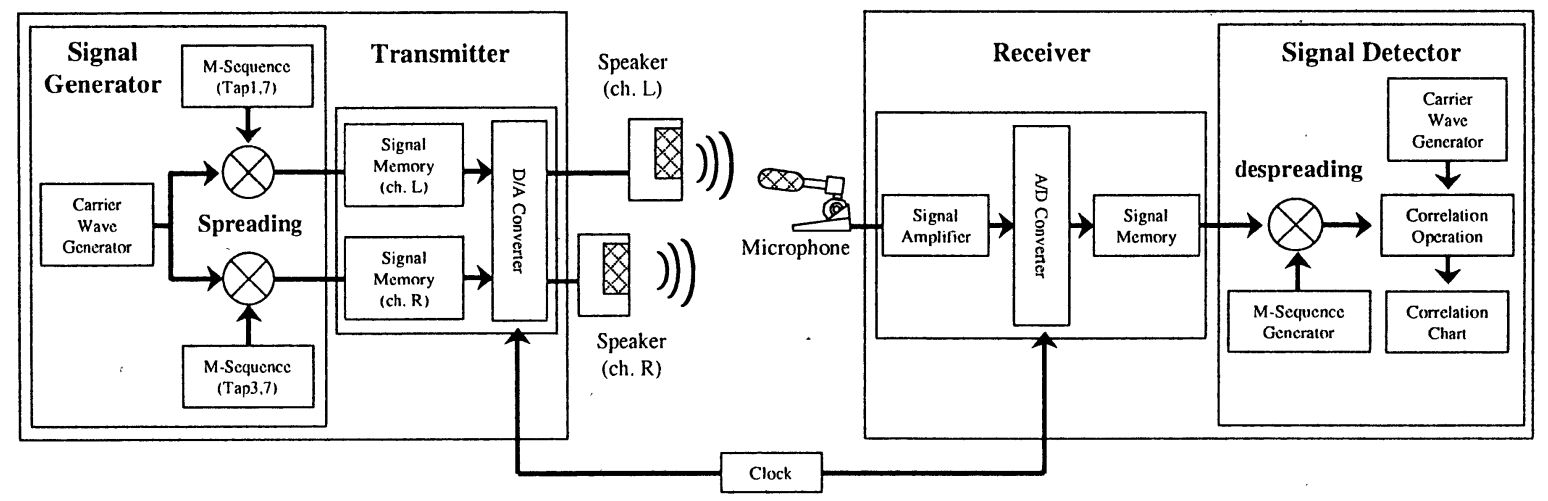

Fig. 3 A block diagram of the experimental setup

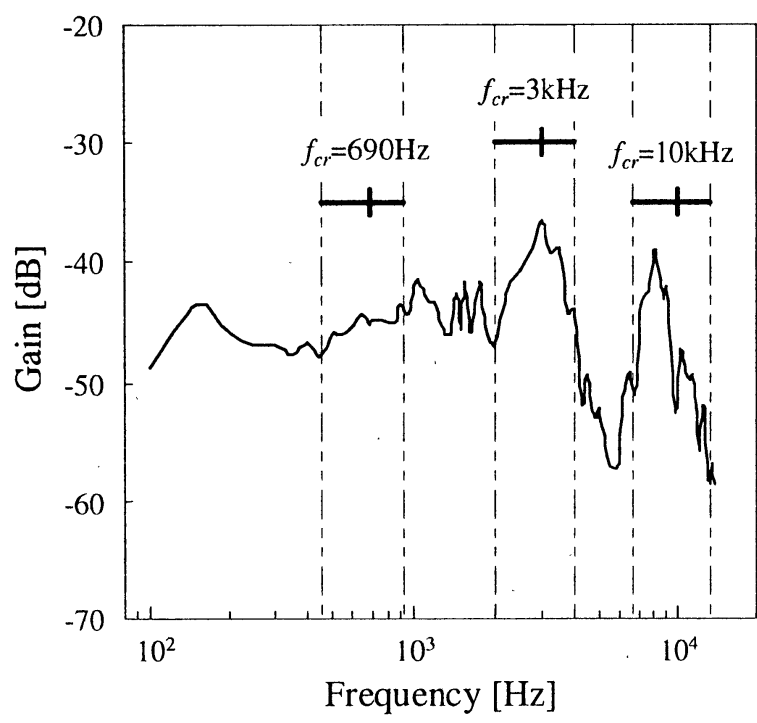

Fig. 4 Transmission characteristic with frequency for the used speaker-microphone spaced at $30 \mathrm{~cm}$

受信機側では，音波の送信が開始されると同時に受信が開 始され，マイクによって電圧に変換された音波の信号を $\mathrm{A} / \mathrm{D}$ 変換部でデジタルの波形データに変換し受信波形メモリに保 存していく．受信が終了した後，信号識別部が波形メモリに 保存された波形デー夕を読み出して相関計算を行ない信号の 識別処理を実行する.

送信側の $\mathrm{D} / \mathrm{A}$ 変換部と受信側の $\mathrm{A} / \mathrm{D}$ 変換部はサンプリン グに怙けるタイミングのずれを防ぐために同一のクロック信 号によって動作させている，以上のような手順によって，ス ペクトル拡散音波の送受信の実験を行なう.

\section{3 搬送波の周波数とスペクトル拡散音波の帯域}

スペクトル拡散信号の带域幅は搬送波の周波数 $f_{c r}(=$ $1 / T)[\mathrm{Hz}]$ を中心に $2 / T_{c}$ で表わされる ${ }^{18)}$. 本研究では $T_{c}=3 T$ に設定して実験を行なうので, 带域幅は $2 f_{c r} / 3$ となる.Fig. 4 は送信音源一空中伝播路 $(30 \mathrm{~cm})$ 一受信音源 系の周波数特性である. 3 つの搬送波周波数における帯域幅 をそれぞれ，図中に示す。帯域内における利得の変動は，搬 送波周波数 $0.69 \mathrm{kHz}$ では約 $-5 \mathrm{~dB}, 3.0 \mathrm{kHz}$ では約 $-10 \mathrm{~dB}$, $10 \mathrm{kHz}$ では約 $-20 \mathrm{~dB}$ となっている.

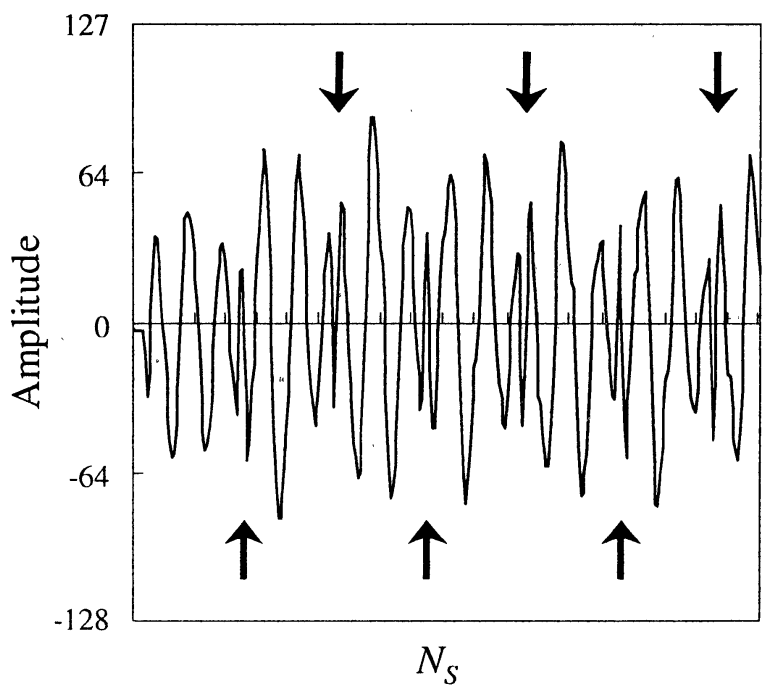

Fig. 5 A part of the received signal waveform after air transmission over a distance of $0.5 \mathrm{~m}$. Solid arrows indicate locations of phase shift for the modulation

\section{3. 実験結果と検討}

\section{1 スペクトル拡散音波の受信波形と相関関数}

$0.69 \mathrm{kHz}$ の搬送波周波数に（Tap1,7）の M 系列擬似乱数 符号で位相変調を行ない, 送信音源 (スピーカ ch.L) から音 波として送信し，0.5m 隔てた受信音源（マイク）で受信した 受信波形メモリの信号を Fig. 5 に示す。送信波形メモリの信 号 (Fig. 2) は一定の振幅の正弦波で，位相変調点がめいりょ うであるが，実際の受信信号は振幅が一定にならず，Fig. 5 の矢印で示すようにかろうじて位相の転移点が確認できる程 度に歪んだ波形であることがわかる。これは，送信音源一空 中伝播路 $(30 \mathrm{~cm})$ 一受信音源系の周波数特性（Fig. 4）によ る帯域制限，反射波の重冨などによるものと考えられる.

この受信波形に対して，送信側と同じ（Tap1,7）の M 系列 符号を用いて逆拡散して得られた相関関数を，伝播距離 $5 \mathrm{~m}$, 10m，20m についておのおの Fig. 6(a)，(b)，(c)に示した. 縦軸は相関值で, 横軸 $N_{s}$ は前述したサンプル位置を示す番 号である.この $N_{s}$ は時間軸に相当するが，Fig.6では任意 の位置で示している.Fig. 6 に示すように，逆拡散後の相関 
(a) Propagation Distance $5 \mathrm{~m}$

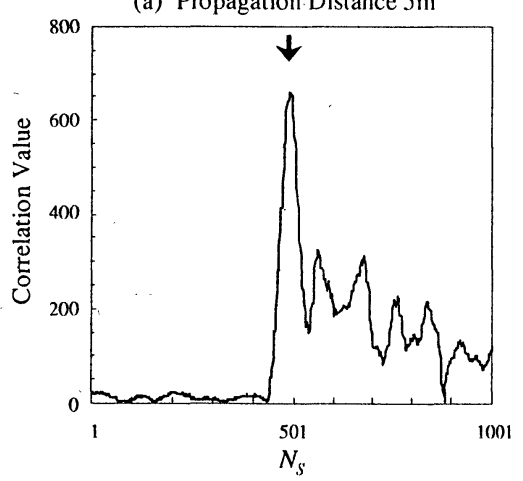

(b) Propagation Distance $10 \mathrm{~m}$

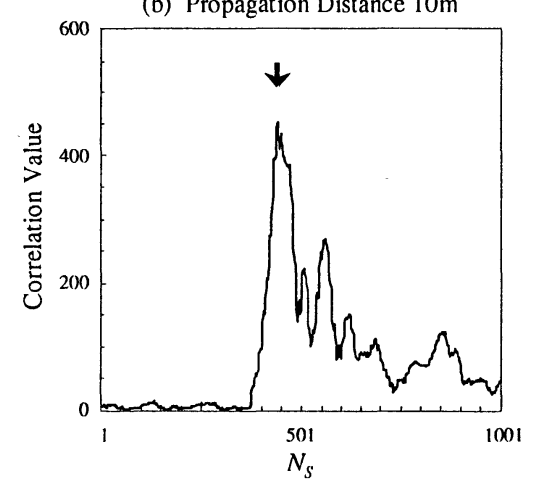

(c) Propagation Distance $20 \mathrm{~m}$

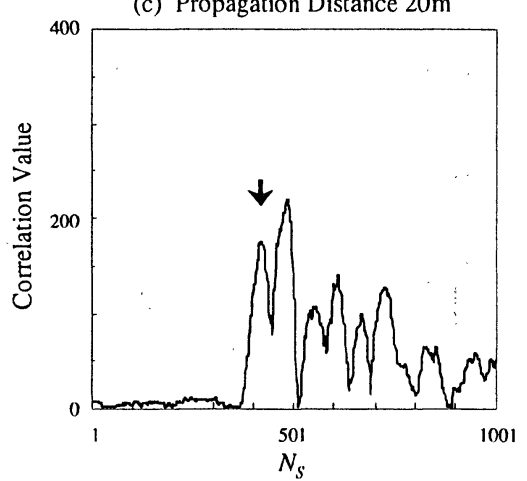

Fig. 6 Resultant correlation values as a function of the sampling number $N_{s}$ for (a)5-, (b)10-, and (c)20-m propagation distances. Solid arrows indicate the detection of signal arrival from the transmitter

(a) Signal: Noise $=1: 1$

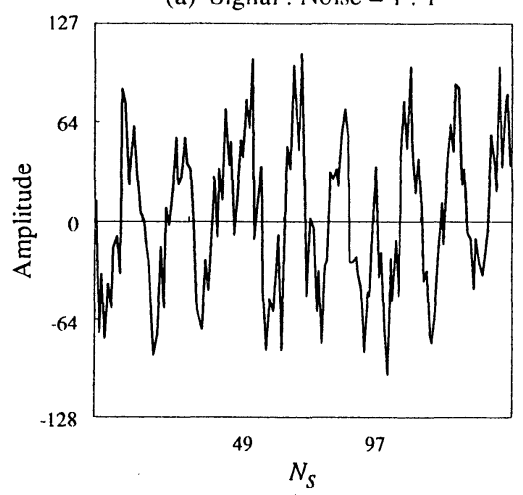

(b) Signal : Noise $=1: 2$

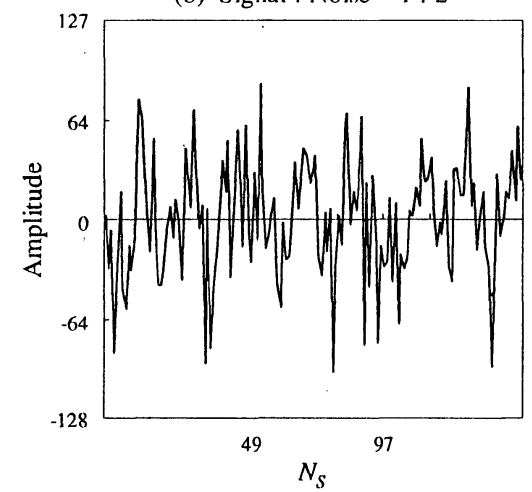

(c) Signal: Noise $=1: 4$

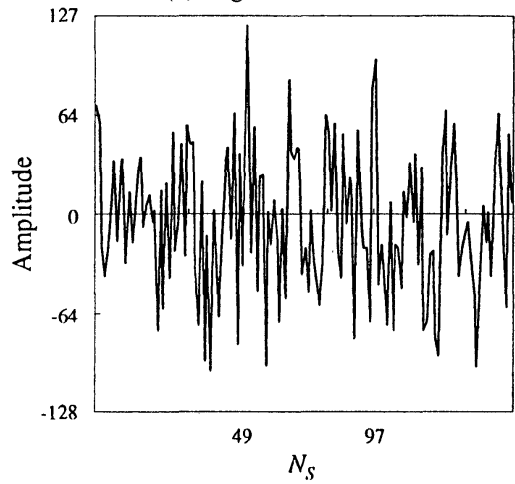

Fig. 7 White noise super-imposed signals set at a waveform memory in the transmitter with the signal to noise ratios of (a) 1:1, (b) $1: 2$, and (c) 1:4, as a function of the sampling number $N_{s}$

(a) Signal : Noise $=1: 1$

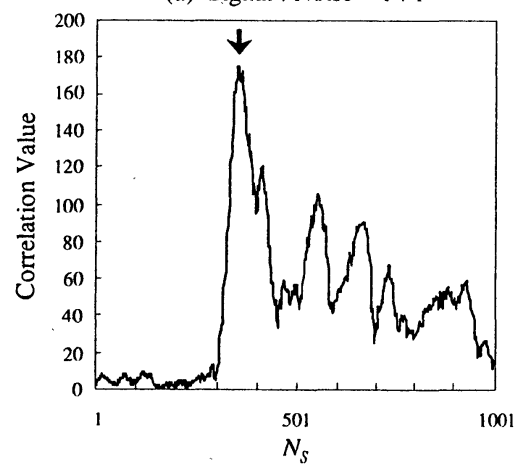

(b) Signal: Noise $=1: 2$

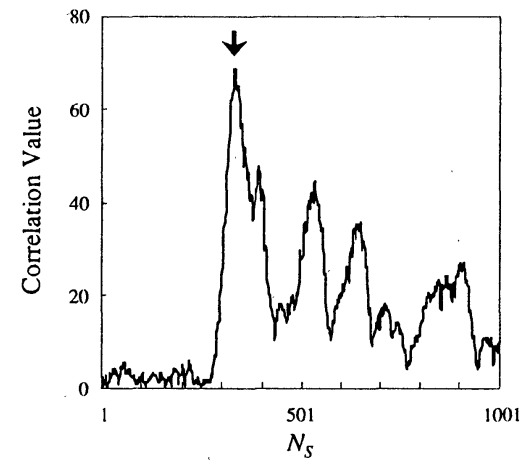

(c) Signal: Noise $=1: 4$

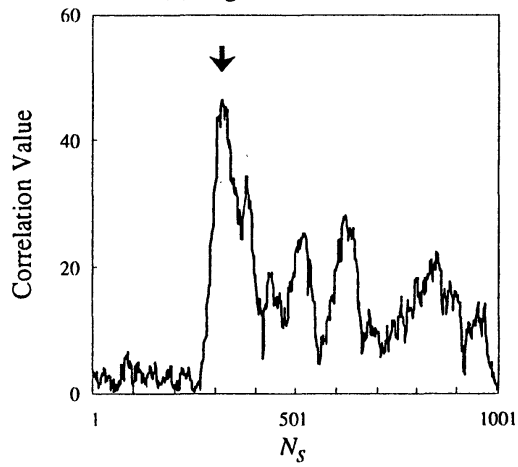

Fig. 8 Resultant correlation values as a function of the sampling number $N_{s}$ for (a) 1:1, (b) 1:2, and (c) 1:4 of the signal to noise ratio, after 20-m propagation. Solid arrows indicate the detection of signal arrival from the transmitter

関数はめいりょうなピーク値を有し，同期捕捉点として正確 に検出できていることがわかる。また，伝播距離が長くなる につれ，受信信号の信号強度が減衰するため相関値が減少し， 直接波を示す最初の相関ピーク後に反射波の受信を示すピー クがより顕著に現れているのがわかる．本実験では，直接波 が最初に到達するものとし, 最初の相関値ピークを捕捉位置
とした。また，実験は幅 $2.4 \mathrm{~m}$, 高さ $2.5 \mathrm{~m}$, 長さ $25.0 \mathrm{~m}$ の廊 下で行なっている. Fig. 6(c) のように最初のピーク值より， 反射波と考えられる 2 番目以降のピーク值が大きくなる場合 もある。これは, 伝播空間である廊下内において伝播経路長 がわずかに異なる反射波が強め合って直接波強度を上回るた めと考えられる。 
(a) $d=0.18 \mathrm{~m}$

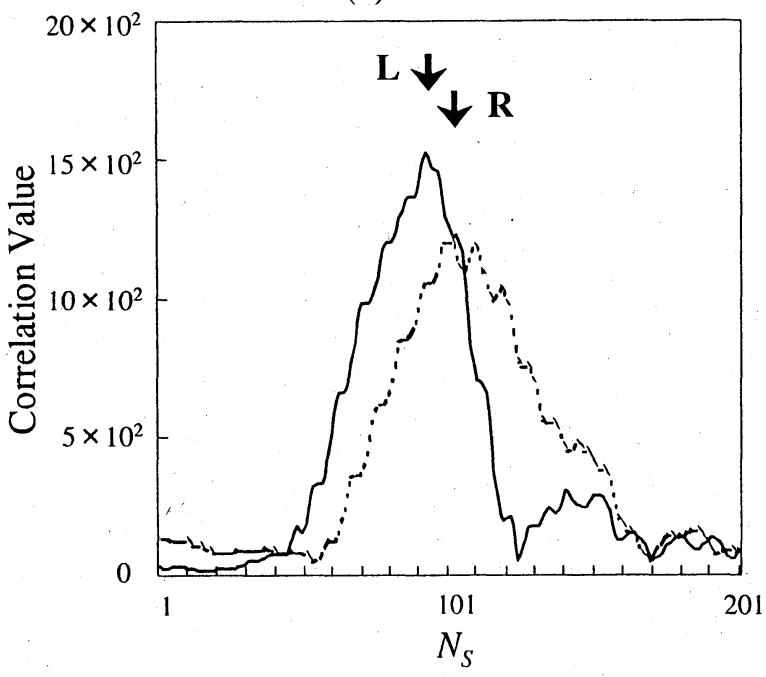

(b) $d=0.72 \mathrm{~m}$

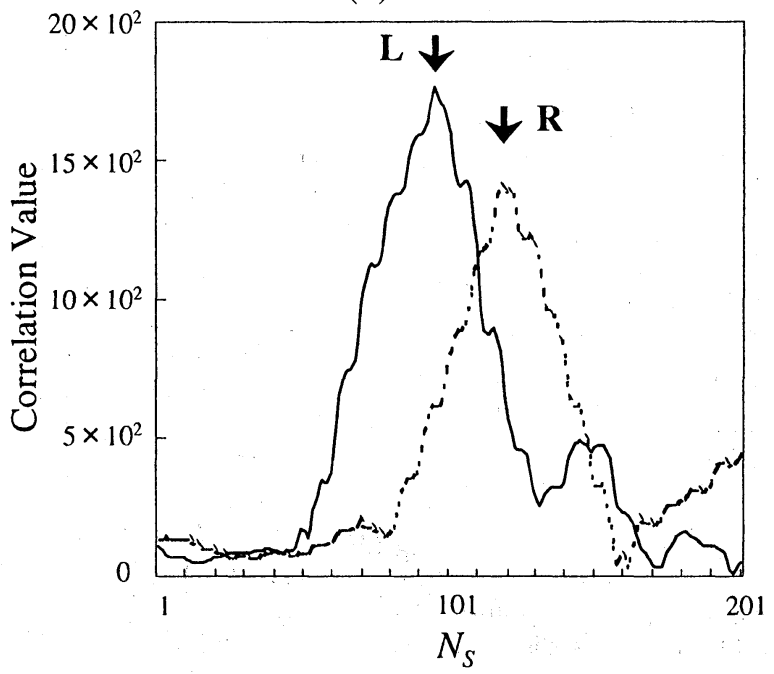

Fig. 9 Correlation values as a function of the sampling number $N_{s}$ for two different Msequence codes simultaneously launched from the two speakers (ch.L and ch.R), distanced at (a)0.18-, and (b)0.72-m. Solid and dashed curves show the correlation values for signals from ch.L and ch.R, respectively. Solid arrows indicate the detection of signal arrival from the transmitters

(a) Carrier Frequency $0.69 \mathrm{kHz}$

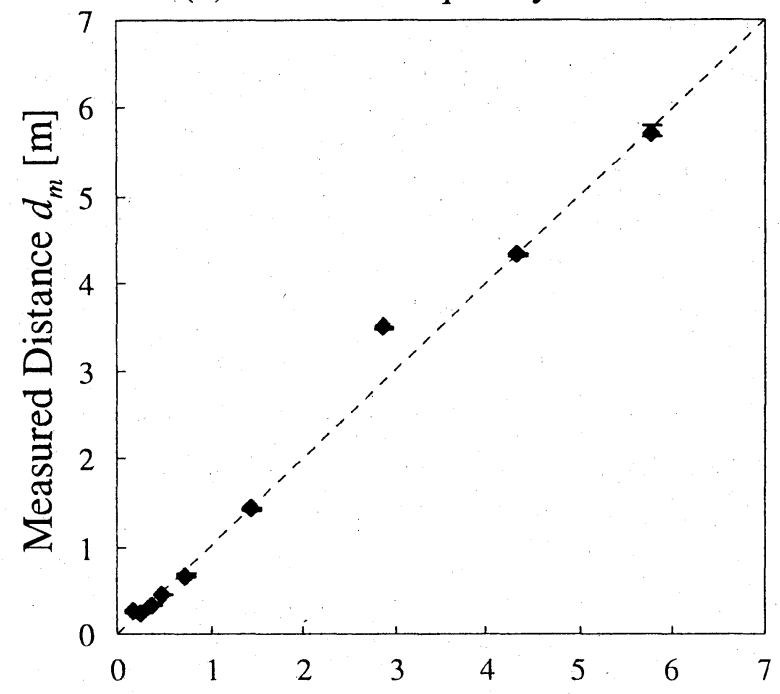

Distance between two speakers $d[\mathrm{~m}]$ (b) Carrier Frequency $3.0 \mathrm{kHz}$

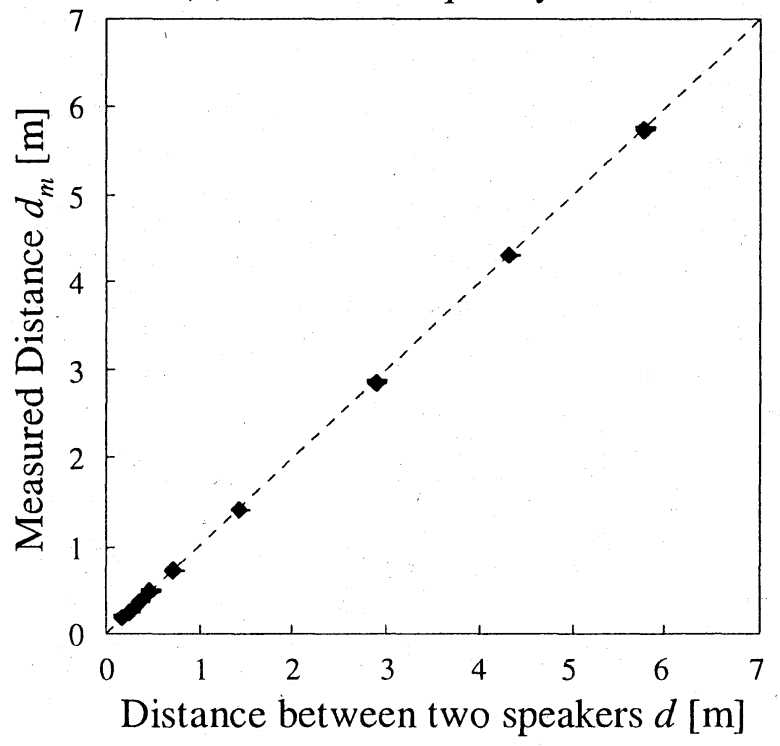

Fig. 10 Measured distances with the distance between the two speakers for the carrier frequencies of (a)0.69- and (b)3.0-kHz

\section{2 而雑音性と信号識別の評価}

スペクトル拡散信号の大きな利点の 1 つは耐雑音性に優れ ていることである. 本研究のように縦波弾性波である音波に おいてどの程度の耐雑音性を示すかを明らかにするために， 白色雑音の重畳下における同期捕捉点の検出実験を行なった。 Fig. 6 と同様の送受信音源を用い, 搬送波周波数 $0.69 \mathrm{kHz}$, 伝播距離が $20 \mathrm{~m}$ になるよう設置した。

送信機・波形メモリ (ch.L) 内に格納されたスペクトル 拡散波形デー夕に対し, 信号対雑音強度比で $1: 1,1: 2,1: 4$ の混合比となるように, 信号 $\left(f_{c r}=0.69 \mathrm{kHz}\right)$ の拡散幅 $\left(2 f_{c r} / 3=0.46 \mathrm{kHz}\right)$ に対し約 6 倍の帯域を持つ白色雑音を
加算して全体の振幅が 8bit となるようにした. Fig. 7 に送信 波形メモリ内の白色雑音を重畳した送信波形 (a) 1:1, (b) 1:2, (c) 1:4 を示す. Fig. $7(\mathrm{a}) \sim$ (c) はいずれも拡散擬似乱数符号 の最初の 3 ビットまでの雑音を含む位相変調波形である。本 実験では，前述のとおり搬送波 3 周期を拡散擬似乱数符号 1 ビット $\left(1\right.$ チップ長: $\left.T_{c}[\mathrm{~ms}]\right)$ としているので, 1 周期 16 サ ンプルとすると, $N_{s}=49,97$ が位相の転移点となる。これ らの信号を受信し, Fig. 6 と同様に逆搪散して相関関数を求 めると Fig. 8(a)1:1，(b)1:2，(c)1:4 となる. Fig. 8 に見られ るように白色雑音に対しては，いずれの混合比の信号におい ても同期捕捉点を示す相関值のピークが得られている。また, 


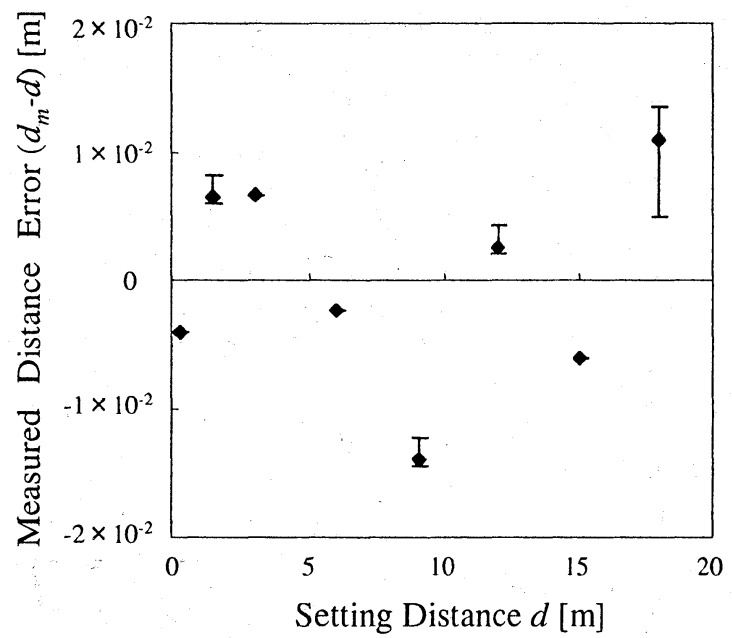

Fig. 11 Measured distance error as a function of the acoustic travelling distance in the case of the $10-\mathrm{kHz}$ carrier frequency

雑音強度が増加するにしたがって相関値が小さくなるのは混 合信号全体の振幅を 1 としているため, 相対的に信号強度が 小さくなっていることによるものである、スペクトルが広い 白色雑音に対して, スペクトル拡散信号が高い利得で検出さ れるのは一般的に認めら机ている知見であるが, 電波に比べ てはるかに帯域制限を受けやすい環境下の音波についてもそ の利点が認めら机ることが明らかとなった。

同一の周波数で，きわめて近い符号列すなわち符号間相関 の高い信号による妨害行為（ジャミング）はこの議論から除 くことにして，符号間相関の低い $2 つ 0 \mathrm{M}$ 系列乱数符号を 用いて, 同時に送信した $2 つ の$ 音波の信号識別能力を実駼的 に検討することは重要である.

Fig. 9 は搬送波周波数 $0.69 \mathrm{kHz}$ を用い, 2 つの送信音源 (スピーカ ch.L, ch.R)に(Tap1,7)，(Tap3,7）の M 系列 を割り当て同時に送信し，受信音源での受信後に逆拡散した 相関関数の波形を示している. 実験では ch.L を受信音源か ら $0.5 \mathrm{~m}$ の位置に, また ch.L と ch.Rにあらかじめ距離の差 $d$ を与えており, Fig. 9(a)は $d=0.18 \mathrm{~m}$, (b) は $d=0.72 \mathrm{~m}$ の場合である. 図中矢印 $\mathrm{L}, \mathrm{R}$ はおのおのの音波の同期捕捉 点である相関值ピークを示す。この場合， 2 つの音源の出力 レベルは同一としている. ch.Rは ch.Lより後方に設置され ているため, 受信における相関値ピークの值は ch.Lに比べ やや小さいことがわかる. また ch.L と ch.R の距離差 $d$ に したがい，同期捕捉点の時間差が大きくなることがわかる. Fig. 9 から，符号分割多重において正しく目的の信号のみ検 出が可能であること，また検出時間の差より計測した距離が 設置距離にほほ一致することが明らかとなった。

\section{3 測距実験}

搬送波周波数 $0.69,3.0,10 \mathrm{kHz}$ における測距実験を行な い，それぞれの精度について検討を行なった。 $0.69,3.0 \mathrm{kHz}$ については, Fig. 9 と同様に 2 つの送信源の設置位置差 $d$ を 0.1 6.0m の範囲の任意 9 地点において, 各地点 5 回の計測
を行なった．距離差 $d$ が $6.0 \mathrm{~m}$ 以上になると，後方に設置し た ch.Rの信号が ch.Lに比べて小さくなり，相対的に相関関 数が極端に小さくなるので, $10 \mathrm{kHz}$ については ch.L と受信 音源（マイク）の組み合わせで $0.3 \sim 18 \mathrm{~m}$ の範囲で実験を行 なっている。

Fig. 10(a), (b) は，搬送波周波数 $0.69 \mathrm{kHz}$ と $3.0 \mathrm{kHz}$ の 場合の測距結果を示している. Fig. 10(a) の距離 $d=3.0 \mathrm{~m}$ 近傍で大きな誤差を示した以外は，ほほ直線的な計測結果を 示している。この比較的大きな誤差は，廊下を伝播する反射 波の中には干渉効果でときとして直接波に比べ大きな相関値 ピークを示寸場合があり，そのため直接波のピークの位置が 不明確になったことによるものである。誤差評価では，この 1 計測点は除くことにする。誤差の評価値としてフルスケー ル誤差 $\% F S[\%]$ を,

$$
\% F S=\frac{\left|d_{m}-d\right|}{L} \cdot 100
$$

と定義する.ここで, $d_{m}[\mathrm{~m}]$ は計測値の平均值, $d[\mathrm{~m}]$ は設定 距離, $L[\mathrm{~m}]$ は計測最大距離を示す. $0.69 \mathrm{kHz}$ では $\% F S$ の 平均值として $0.59 \%, 3.0 \mathrm{kHz}$ では $0.21 \%$ 得ら机た。また, Fig. 11 は $10 \mathrm{kHz} に お け る$ 距離に対する測定誤差 $\left(d_{m}-d\right)$ を示している. $L=18 \mathrm{~m}$ として，このときの $\% F S$ の平均 值は $0.037 \%$ となる.このように, 計測の誤差は周波数の増 加と伴に小さくなることがわかる.

$\mathrm{M}$ 系列符号の 1 チップ長は $T_{c}=3 T$ に設定しているため, 音速 $340 \mathrm{~m} / \mathrm{s}$ とした場合, 1 チップの距離は搬送波 $0.69 \mathrm{kHz}$ で $1.47 \mathrm{~m}, 3.0 \mathrm{kHz}$ で $0.34 \mathrm{~m}, 10 \mathrm{kHz}$ では $0.1 \mathrm{~m}$ となる。沉 用の GPS では，一般に 1 チップ距離の $1 / 10$ 程度の誤差 ${ }^{19)}$ とされている。本実験では，1チップ距離の $1 / 15(10 \mathrm{kHz})$ から $1 / 40(0.69 \mathrm{kHz})$ の誤差となる. 擬似乱数符号に上る 拡散信号は復調するときにサンプル時間ごとに積和演算を 行なっている. 各周波数での誤差はサンプル数に換算すると $0.69 \mathrm{kHz}$ で $1.1,3.0 \mathrm{kHz}$ で $1.7,10 \mathrm{kHz}$ では 3.2 サンプルに 相当する.こ玌からサンプリング周波数を高くすればさらに 精度が上がることも期待できるが, 演算時間の増大をまねき 実用性が損なわ札る。誤差が相関関数ピーク值のサーチ時の 数サンプルに留まっていることが明らかになったことは, 実 用システムの設計にとって大きな知見といえる.

一般的な超音波パルスエコー型測距センサの測距精度は, 周波数を上げることにより計測距離分解能が向上し， $40 \mathrm{kHz}$ で $0.01 \mathrm{~m}$ 程度 ${ }^{20)}$ とされている. また周波数 $200 \mathrm{kHz}$ でも, 距 離分解能は $2.00 \times 10^{-3} \mathrm{~m}$ 程度となる ${ }^{20)}$. 本実験の結果は, スペクトル拡散音波の距離精度を決定する要素としては周波 数だけではなく, チップ長, サンプル周期があるため, 搬送 波周波数 $10 \mathrm{kHz}$ の低い周波数においても, 計浿距離 $18 \mathrm{~m}$ 内 に打いて，\%FS 平均值が $0.037 \%$, 距離にして数 $\mathrm{mm}$ とい う小さな誤差で測定できることが明らかとなった。

\section{4. おわりに}

本論文では, 擬似乱数符号列として系列長 127 の M 系列 
を用いて, 音波を直接位相変調したスペクトル拡散可聴音波 信号を用いて, 受信信号の逆拡散, 耐雑音評価, 異なる $2 つ$ の符号系列の多重分割信号識別, さらに測距実験による測距 誤差評価を行なった。一連の実験結果は, GPSにおける電波 帯のスペクトル拡散波による測位のための擬似距離測定にお けるアナロジーとして検討を加え, 室内における局地的測位 が可能であることを初めて明らかにした。

実験では, 汎用の送信音源 (スピーカ) /受信音源（マイ ク）の帯域制限下において, 位相変調した縦波弾性波が逆拡 散によって識別できる相関関数波形として取得でき，耐雑音 性, 多重分割送信時の信号識別性が優れていることが確認さ れた。またこのシステムによる測距実験では，0.69，3.0，

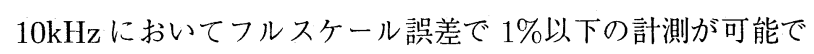
あることが明らかになった。特に, $10 \mathrm{kHz}$ では, $18 \mathrm{~m}$ の距離 範囲で $0.037 \%$ （約 $7 \mathrm{~mm}$ ）の誤差が実現された。こ机らの誤 差は，搬送波周波数に加えて，チップ長の設定，信号のサン プリング周波数によって評価でき, GPS と同じ概念で説明で きることが示された。

実用的には，超音波の実験が望まれるが，計測に広く利用 されている市販の沉用圧電素子型超音波トランスデューサの 帯域は, 今回用いた可聴域の送受信系に比べるとさらに狭 い。たとえば， $40 \mathrm{kHz}$ を中心に $10 \mathrm{kHz}$ において -15 から $-20 \mathrm{~dB}$ の減衰を示す ${ }^{21)}$. 本実験結果から，これらを送受信 音源として利用した場合, 擬似乱数 M 系列による搬送波へ の変調チップ長を $T_{c}=10 T$ とし, 搬送波周波数 $40 \mathrm{kHz}$ を 中心に $8 \mathrm{kHz}$ の帯域幅に周波数スペクトルのメインローブを 納めるようにす机ば実現性が見出せることになる。この場合, 1 チップ距離は $8.5 \mathrm{~cm}$ となるが, その $1 / 10$ 程度の精度は確 保できると概算できる. また, 擬似乱数符号列のコード長を 長くして, 拡散比を高めることにより，受信機における $\mathrm{S} / \mathrm{N}$ 比を高くすることによっても, 精度の向上と計測距離範囲を 拡大することも可能であろう。

今後, 実際の測位となると, 少なくとも 3 点からの測距が 必要となり, 相関性の低い符号列を複数用意することが必要 になるが, GPS と異なる点は本方式では信号源が固定擬似 衛星となり, 衛星の移動にかかわる複雑な処理過程がかなり 簡便化されると考えられる. マルチパスについても, 音波の 速度から反射波と直接波の識別は比較的容易になる。音波は 電波に比べて, 温度, 空気の極度な摇らぎに, 影響を強く受 けやすいという特有の問題もある。また, 電波と共通のドッ プラー効果, 遠近問題なども残されている. 本研究は, これ らの問題を考虑したアルゴリズムを処理系に用いて, 擬似固 定衛星である送信音源を適当に配置す机ば, 室内測位に十分 応用可能であることを示唆するものである.

謝辞 本研究において実験システムの構築, 計測実験に協 力してくださった, 三上孝一氏 (現. 松下電器産業), 武信誠 一氏 (本学大学院情報システム学専攻博士前期 2 年生) に深 く感謝致します.

\section{参 考文 献}

1）青柳, 木口, 常峰, 高野: 簡易バーコードランドマークの画像 認識と傾斜補正による移動ロボットの位置·姿勢計測, 電学論 C, 121-2, 375/384 (2001)

2) 岩田, 高橋, 佐々木, 高野：LED 灯台を用いた移動ロボット 用位置姿勢検出システム, 精密工学学会, 61-11, 1579/1583 (1995)

3) M.Drumheller : Mobile Robot Localization Using Sonar, IEEE Trans. On Pattern Anal. Machine Intell., PAMI-9$2,325 / 332(1987)$

4）勝屋, 八木, 谷内田 : 全方位視覚センサによる動環境での静 止環境地図㧍よび自己位置の同時推定, 日本ロボット学会誌, 17-3, 432/438 (1999)

5）日本航海学会 GPS 研究会著：GPS シンポジウム 2001，194, 正陽文庫 (2001)

6) D.Yun, H.Jun and C.Kee: Precise Calibration of Pseudolite Positions In Indoor Navigation System, Proc. of the 6th GPS Workshop, 679/684 (1999)

7) 三上, 川根, 武信, 崔, 伊与田, 渡辺, 久保田: 拡散変調音波 の耐雑音性の評価, 第 33 回計測自動制御学会北海道支部学術 講演会論文集, $25 / 26$ (2001)

8) A.Yamane, K.Mikami, S.Takenobu, Y.Choi, T.Iyota, K.Watanabe and Y.Kubota: Development of Range Sensing System Using Spread Spectrum Sound Waves, Proc. of the 10th Int. Conf. on Advanced Robotics (ICAR2001), $671 / 675$ (2001)

9) J.Borenstein and Y.Koren : Noise Rejection for Ultrasonic Sensors in Mobile Robot Applications, Proc. of the 1992 IEEE Int. Conf. on Robotics and Automation, 1727/1732 (1992)

10）丹沢, 清弘, 森: 屋外移動ロボットのための雑音に強い超音波 センサ, 日本ロボット学会誌, 15-4, 542/549 (1997)

11）深川I, 森本, 北川1, 今田, 下平, 沖村: 音波式ガ ス温度 - 流量 計測における信号処理法と試験信号波形について, 計測自動 制御学会論文集, 37-1, 21/29 (2001)

12）和高, 永塚, 三須, 浦崎, 小池：相補系列を用いた符号化位相 変調パルス压縮超音波探傷法, 電子情報通信学会技術研究報 告, US89-34, 15/22 (1989)

13）棚田, 佐々木, 前田, 堀: 実数直交擬似乱数系列を用いた超 音波測距方式, 電子情報通信学会スペクトル拡散通信研究会, SS87-27, 63/71 (1987)

14）大槻, 奥島：海中における超音波伝搬状況観測のための M 系 列 2 周期信号法, 日本音響学会誌, 38, 619/623 (1982)

15）蜂屋，大槻，奥島：M 系列信号音波を用いた相模湾の多経路 伝搬音波の観測，海洋音響学会誌，17, 106/113 (1990)

16）横川光雄著：スペクトル拡散通信システム，145/25, 科学技術 出版社 (1988)

17）柏木濶著：M 系列とその応用，16，昭晃堂 (1996)

18）丸林, 中川, 河野共著: スペクトル拡散通信とその応用, 22, 電子情報通信学会 (1998)

19）日本測地学会編著：GPS 一人工衛星による精密システム一, 26 , 日本測量協会 (1989)

20）谷腰欣司著: 超音波とその使い方 超音波七ンサ・超音波モ一 夕, 102, 日刊工業新聞社 (1994)

21）村田製作所：http://www.murata.co.jp/index.html, 製品力 タログ（送信器 MA40S4S, 受信器 MA40S4R) 


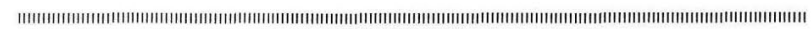

$$
\text { [著者紹介] }
$$

山 根 章 生 (学生会員)

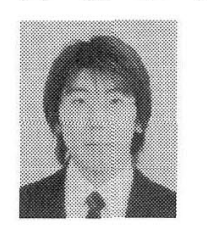
2000 年創価大学工学部情報システム学科卒業. 現在, 同大学院工学研究科情報システム学専攻博 士後期課程在学中. 日本ロボット学会会員.

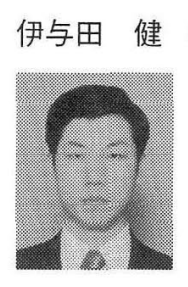

\section{敏（正会員）}

1986 年東北大学工学部応用物理学科卒業. 92 年同大学院工学研究科応用物理学専攻修了. 現在, 創価大学工学部講師. 画像による環境認識, 超音 波による距離計測と測位システムなどの研究に従 事. 日本物理学会, 電子情報通信学会の会員. (工 学博士)

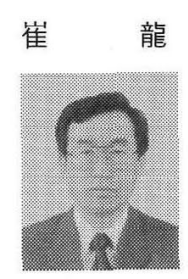

1983 年韓国中央大学工学部電子計算学科卒業. 95 年神戸大学大学院自然科学研究科博士課程シ ステム科学専攻修了. 現在, 創価大学工学部講師. ロボットビジョン, 自律移動ロボットの研究に従 事. 日本ロボット学会, 電子情報通信学会などの 会員. (工学博士)

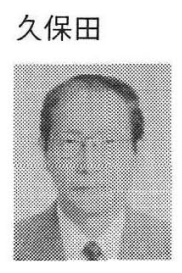

譲 (正会員)

1963 年室蘭工業大学工学部機械工学科卒業. 68 年北大大学院工学研究科精密工学専攻博士課程単 位取得退学, 同年室闌工業大学講師. 現在, 創価 大学工学部教授. 制御, ロボット挙動などの研究 に従事. 日本機械学会, 日本ロボット学会などの 会員. (工学博士)

\section{渡 辺一弘(正会員)}

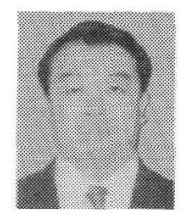

1976 年慶應義塾大学工学部電気工学科卒業. 81 年同大学院工学研究科電気工学専攻博上課程修了. 現在, 創価大学工学部教授, 同学部情報システム 学科長. レーザの光情報装置への応用, 光ファイ バセンサ，自律移動ロボットの自己位置認識シス テムなどの研究に従事. 電気学会, 日本ロボット 学会, 応用物理学会, 可視化情報学会などの会員. (工学博士) 